\title{
Preparation and Properties of Organic Dispersions of Monodisperse Silica Receptor Colloids Grafted with Calixarene Derivatives or Alkyl Chains
}

\author{
A. M. Nechifor, ${ }^{\dagger, l l}$ A. P. Philipse, ${ }^{*}$, F. de J ong, ${ }^{\dagger}$ J . P. M. van Duynhoven,, \\ R. J. M. Egberink, ${ }^{\dagger}$ and D. N. Reinhoudt ${ }^{\dagger}$
}

\begin{abstract}
Department of Organic Chemistry, University of Twente, P.O. Box 217, 7500AE Enschede, The Netherlands, Van't Hoff Laboratory for Physical and Colloid Chemistry, University of Utrecht, Padualaan 8, $3584 \mathrm{CH}$ Utrecht, The Netherlands, and Department of Chemical Analysis, University of Twente, P.O. Box 217, 7500AE Enschede, The Netherlands
\end{abstract}

Received J anuary 22, 1996. In Final F orm: May 24, 1996 ${ }^{\otimes}$

\begin{abstract}
We introduce cation-selective receptor colloids consisting of a monodisperseinorganic silica core grafted with an organic layer containing calixarene receptor molecules. The surface layer is designed to provide chemical sel ectivity (toward $\mathrm{Cs}^{+}$) as well as colloidal stability in organic solvents of interest in which silica spheres otherwise may flocculate. Grafting procedures for commercial- and laboratory-made silica dispersions are investigated for 25,27-bis[1-(11-hydroxyundecyl)oxy]calix[4]arene-crown-6 (designed and synthesized for this purpose), octadecyl al cohol, and mixtures ("cografting") of both compounds. Special attention is given to the nature of the solvent, which markedly influences grafting densities and colloidal stability during and after grafting procedures. NMR, elemental analysis, and light scattering are used to characterize a variety of carefully purified, grafted silica dispersions and to demonstrate, among other things, the presence of calixarene groups on the silica spheres. Preliminary complexation experiments with cesium chlorideare reported. NMR and el ectrophoresis indicatethat calixarene-silica colloids indeed are receptors for cesium cations.
\end{abstract}

\section{Introduction}

Organic surface coatings are of interest for separation processes $^{1}$ as well as for fundamental studies on colloidal model dispersions. ${ }^{2}$ In studies on model colloids the coating is chemically "passive". I ts purpose is mainly to stabilize particles against aggregation in somesol vent or to influence physical interactions between the colloids. ${ }^{3-6}$ In separation techniques, thesurfacecoating of a material may be "active" in the sense that it very selectively binds certain species such as enzymes and other biomolecules (ref 1 discusses many examples of carrier surface groups and their applications in affinity separation).

Alsoin thefield of supramolecular chemistry and liquid membranes, selective binding is a well-documented phenomenon. ${ }^{7-14}$ A versatiledass of molecules which can recognize cations or anions are the calixarenes: cyclic

* Author for correspondence.

† Department of Organic Chemistry, University of Twente.

₹ University of Utrecht.

$\S$ Department of Chemical Analysis, University of Twente.

" On leave from Research Center for Macromol ecular Materials and Membranes, Spl. Independentei 206, Bucharest, Romania.

${ }^{\otimes}$ Abstract published in Advance ACS Abstracts, J uly 15, 1996.

(1) Pieters, B. R.; Williams, R. A.; Webb, C. Magnetic Carrier Technology. In Colloid and Surface Engineering: Applications in the Procees Industries; Williams, R. A., Ed.; Butterworths: Oxford, 1992. (2) Vrij, A.; Philipse, A. P. Model Particles for Concentrated Colloidal Dispersions: from Hard Spheres to Soft Rods; In NATO Advanced Research Workshop on Fine Particles Science and Technology, 1996; in print.

(3) Philipse, A. P.; Vrij, A. J . Chem. Phys. 1988, 88, 6459.

(4) Pathmamanoharan, C. Colloids Surf. 1990, 50, 1.

(5) van Blaaderen, A.; van Geest, J .; Vrij, A. J . Coll oid I nterfaceSci. 1992, 154, 481.

(6) van Blaaderen, A.; Vrij, A. Langmuir 1992, 8, 2921.

(7) Vicens, J ., Böhmer, V., Eds. Calixarenes: A Versatile Class of Macrocyclic Compounds; Kluwer: Dordrecht, 1991.

(8) Huisman, B.-H.; Thoden van Velzen, E. U.; Van Veggel, F. C. J .

M. M.; Engbersen, J . F. J .; Reinhoudt, D. N. Tetrahedron Lett. 1995,

36, 3273-3276.

(9) Schierbaum, K. D.; Weiss, T.; Thoden van Velzen, E. U.; Engbersen, J . F. J .; Reinhoudt, D. N.; Göpel, W. Science 1994, 265, 1413-1415. oligomers produced by condensation of para-substituted phenols with formaldehyde. ${ }^{7}$ These receptors can form self-assembled monolayers on a surface. ${ }^{8-10}$ Suppose cal ixarenes are coval ently bonded to an (inorganic) surface with the "host cavity" protruding into the solution, such that it can pick up the guest molecule. If this surface belongs to a colloidal particle, then one would have a receptor coll oid, which may very specifically collect certain ions from the environment in which it is diffusing.

The aim of the present work is to investigate the synthesis of such a receptor colloid in a stable (nonaggregated) dispersion. The colloid was designed to havea well-defined inorganic core and a grafted organic surface layer containing receptor molecules. (A sketch of this type of colloid is given in Figure 1). This layer endows the colloid with chemical selectivity but at the same time renders the colloid dispersable in an organic solvent of interest.

For the uncoated starting colloids we selected small, fairly monodisperse silica particles (radius $<100 \mathrm{~nm}$ ), and for the active group of the surface coating we choose a calix[4]arene-crown- 6 which specifically binds cesium. ${ }^{11-14}$ From a colloid chemical point of view such calixarene-silica receptor colloids areinteresting because of the possibility to attain and control surface charge (i.e. $\mathrm{Cs}^{+}$) on silica in an organic solvent. Baresilica flocculates in many organicsolvents. Even if sufficient surfacecharge is present to sustain a stabilizing double-layer repulsion, the origin (and amount) of surface charge is often difficult toassess. With respect to separation processes, thesmall,

(10) Thoden van Velzen, E. U.; Engbersen, J . F. J .; De Lange, P.J .; Mahy, J. W. G.; Reinhoudt, D. N. J . Am. Chem. Soc. 1995, 117, 68536862.

(11) Visser, H. C.; Reinhoudt, D. N.; de J ong, F. Chem. Soc. Rev. 1994, 75 .

(12) Rudkevich, D. M.; Mercer-Chalmers, J .D.; Verboom, W.; Ungaro, R.; de J ong, F.; Reinhoudt, D. N. J . Am. Chem. Soc. 1995, 117, 6124.

(13) Ungaro, R.; Casnati, A.; Ugozzoli, F.; Pochini, A.; Dozol, J .-F .; Hill, C.; Rouquette, H. Angew. Chem., Int. Ed. Engl. 1994, 33, 1506.

(14) Casnati, A.; Pochini, A.; Ungaro, R.; Ugozolli, F.; Arnoudt, F.; Fanni, S.; Schwing, M.-J .; Egberink, R. J . M.; de J ong, F.; Reinhoudt, D. N. J . Am. Chem. Soc. 1995, 117, 2767. 

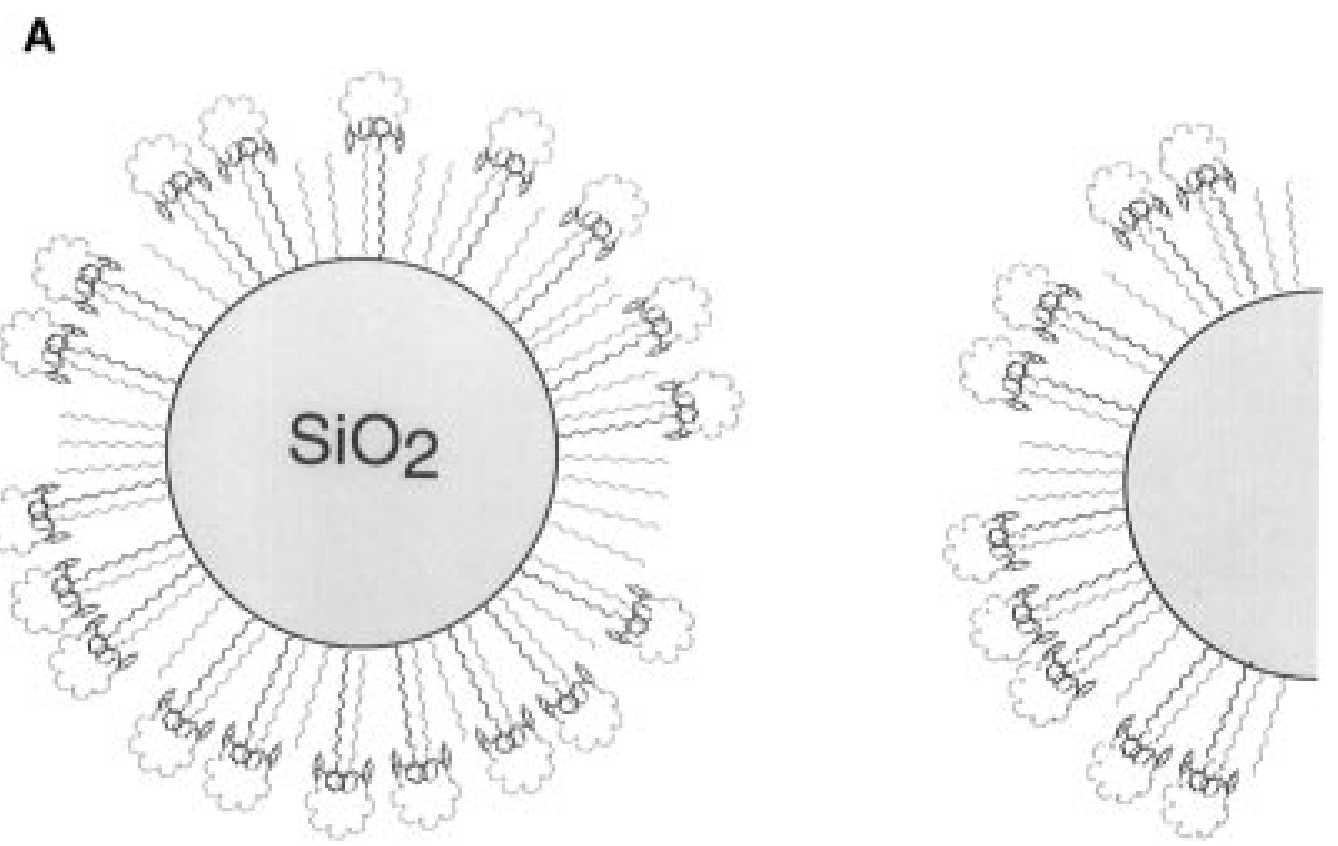

B

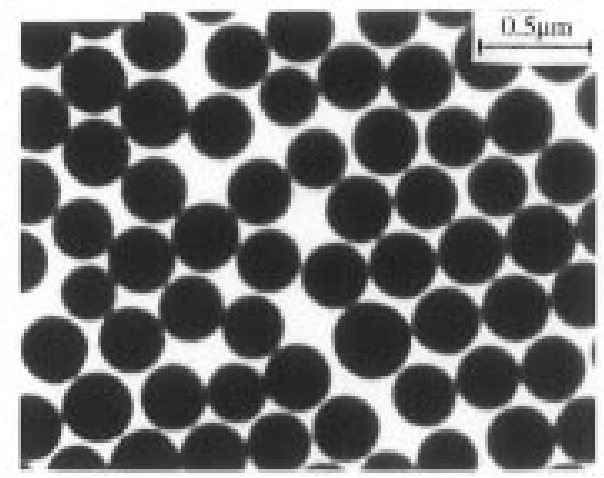

C

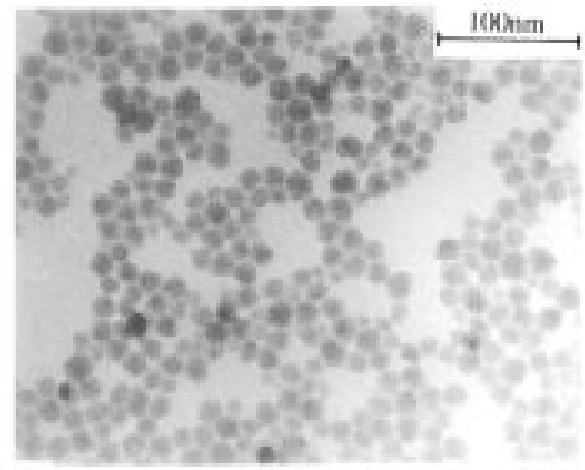

Figure 1. (A) Sketch of silica spheres grafted with alkyl chains. Some chains are functionalized with a macrocyclic receptor (calix[4]arene-crown-6). The sketch is not on scale: the calix[4]arene derivate occupies an area of about $1 \mathrm{~nm}^{2}$, and the radius of Stöber silica spheres on transmission electron micrographs such as in part B is about $85 \mathrm{~nm}$. Part C depicts Ludox particles.

modified colloids combine a high surface area and diffusivity (in comparison with the micron size particles in silica gel $\left.{ }^{15,16}\right)$. Neverthel ess the colloids are in principle still large enough to allow recovery by sedimentation or filtration. Furthermore the modified colloids may be useful for transport experiments as carriers.

The uncoated silica colloids in this study are either commercial Ludox particles (radius $\sim 15 \mathrm{~nm}$ ) in water or laboratory-made silica spheres (radius $\sim 90 \mathrm{~nm}$ ) in ethanol-ammonia, following Stöber. ${ }^{17}$ The small Ludox particles are convenient for NMR because of their high specificsurfacearea. TheStöber spheres werein addition selected to check the influence of the type of silica on the properties of the final coated dispersions. Moreover, our coating procedures can becompared with well-established ones for these Stöber spheres. 2,18,19

The first step in our experiments was the design and synthesis of an appropriatecalixarenederivate. It is wellknown that surface silanol groups from silica particles can be esterified with octadecyl alcohol to yield colloids

(15) Glennon, J . D.; O'Conner, K.; Srijaranai, S.; Manly, K.; Harris, S. J .; McKervey, M. A. Anal. Lett. 1993, 26 (1), 153.

(16) J osic, D.; Reutter, W.; Reusch, J .J . Chromatogr. 1989, 476, 309. 62.

(18) van Helden, A. K.; J ansen, J . W.; Vrij, A. J . Colloid I nterfaceSci. 1981, 81, 354.

(19) Philipse, A. P.; Pathmamanoharan, C. J . Colloid Interface Sci. 1993, 159, 96. with a dense alkane brush grafted on their surface. 2,18,19 Stable dispersions of small grafted particles in a variety of organic solvents can be obtained. This motivated us to synthesizea cal ix[4]arene-crown-6-ether with twopendant undecyl chains with terminal $\mathrm{OH}$ groups, which can react with the silica surface. A terminal triethoxysilane group is also an option for grafting purposes, 3,6 but we preferred a monofunctional group which promotes monolayer formation. (It also allows a better comparison of occupied area per molecul e with results from Langmuir-Blodgett films and with grafting densities of alkyl chains on silica.) M oreover, a "cografting" procedureis conceivablein which a mixture of the calixarenederivateand octadecyl al cohol is used. Such a variablecoating composition may beuseful to optimize colloidal stability in a certain solvent.

The second major issue in our study was the control of the colloidal stability of the silica dispersions during the various processing steps. It is not sufficient to master the chemistry needed to synthesizeand graft thecalix[4]arene derivate. One also has to avoid aggregation of the small colloids to large (visible) flocs; otherwise one loses the advantages over silica gel mentioned earlier. For example theaccessiblesurfacearea decreases, and particlediffusion vanishes. Moreover, in situ characterization of dispersed particles with light scattering is not possible if extensive aggregation takes place.

Colloidal stability of grafted particles requires sufficient affinity between thegrafted surfacelayers and thesolvent. 
If the layers experience a "poor solvent", they will stick together and induce aggregation. The inter play between surface layers and solvents is very subtle, and even marginal changes in solvent composition may produce colloidal instability. The fundamental reason for this sensitivity is the large surface (interaction energy) of colloids in comparison with molecules, whereas the thermal translational energy is the same. ${ }^{2}$

What is required is a common good solvent for the charged "bare" silica particles, the less polar organic molecules, and the final grafted particles. In addition the boiling point of the solvent must be high enough to allow removal of water and lower alcohols (in which the initial silica is dispersed) by distillation. We selected 2-nitrophenyl octyl ether (NPOE) and triethyl phosphate (TEP) and performed in both solvents (co)grafting with 25,27-bis[1-(11-hydroxyundecyl)oxy]calix[4]arene-crown6 and octadecyl alcohol.

NPOE was chosen because it is a good solvent for calixarenes. Moreover, with respect to possible applications, it is also being used in supported liquid membranes as thecarrier solvent for cal ixarenes in the porous polymer membrane, separating the aqueous source and the receiving phases. ${ }^{11}$ TEP was selected because of its ability (in exploratory experiments) to disperseboth charged and hydrophobic silica particles.

After grafting of silica in TEP or NPOE, thedispersions were purified by removing unreacted grafting agents by extensive centrifugation procedures. ${ }^{13} \mathrm{C} \mathrm{CP} \mathrm{MAS,}{ }^{1} \mathrm{H}$ NMR MAS, and TOCSY NMR experiments were performed to investigate the presence of 25,27-bis[1-(11undecyl )oxy]calix[4]arene-crown- 6 and octadecyl chains on thesilica particles. ${ }^{20,21}$ In addition, elemental analysis was carried out for supporting evidence and to estimate grafting densities on the silica.

Any rapid flocculation of particles during or after grafting procedures is easy to observe visually. Lightscattering measurements on dispersi ons were performed to detect any small aggregates in the dispersions. Both light scattering and transmission electron microscopy were used to determine the size of (grafted) silica particles.

Finally, dispersions of 25,27-bis[1-(11-undecyl)oxy]calix[4]arene-crown-6 silica colloids in chloroform were brought in contact with an aqueous cesium chloride solution. ${ }^{1} \mathrm{H}$ MAS NMR spectroscopy was used toestablish whether the modified silica in these preliminary complexation experiments indeed behaves as a receptor colloid toward cesium. Electrophoresis experiments were conducted to find additional evidence for $\mathrm{Cs}^{+}$on silica particles.

\section{Experimental Section}

2.1. Synthesis of Calix[4]arene Derivative. All compounds were of reagent purity and used as supplied unless stated otherwise. Commercial dichloromethane was freshly distilled. Acetonitrile was stored over molecular sieves $(3 \AA)$. Column chromatography separation was carried out using silica gel (0.040-0.063 nm, Kieselgel 60, Merck). Melting points were measured on a Reichert melting point apparatus and are uncorrected. Refractive indices were determined with a Carl Zeiss 37865 (Germany) apparatus. ${ }^{1 H}$ NMR spectra, recorded in $\mathrm{CDCl}_{3}$ at $250 \mathrm{MHz}$ on a Bruker $\mathrm{AC} 250$ spectrometer at room temperature $\left(21^{\circ} \mathrm{C}\right)$, were referenced totetramethylsilane(TMS) at 0.00 as an internal standard. ${ }^{13} \mathrm{C}$ N M R spectra were recorded on a Bruker AC 250 spectrometer. Fast atom bombardment (FAB) spectra were obtained with a Finnigan MAT 90 mass spectrometer, using 3-nitrobenzyl alcohol as a matrix. Microanalytical samples were dried for at least $48 \mathrm{~h}$ at $15 \mathrm{mmHg}$.

(20) Fitch, W. L.; Detre, G.; Holmes, C. P.; Shoolery, J . N.; Keifer, P. A. J . Org. Chem. 1994, 59, 7955.

(21) Eads, T. M.; Weiler, R. K.; Gaonkar, A. G. J . Colloid Interface Sci. 1991, 145, 466.
Differential scanning cal orimetry (DSC) results were recorded with a M ettler DSC12E only for thefinal product. When reactions were performed under a dry argon atmosphere, all glassware was flame dried. Langmuir-Blodgett films were studied for compounds 4 and 5 (See Figure 2).

The starting calix[4]arene (1) was synthesized as described elsewhere. ${ }^{22}$

11-Bromoundecyl 2-tetrahydropyranyl ether (2) was obtained from 11-bromoundecan-1-ol and dihydropyran according to a literature procedure ${ }^{23}$ in $85 \%$ yield.

25,27-Bis[(11-((2-tetrahydropyranyl)oxy)undecyl )oxy]calix[4]areneEther (3). A mixture of calix[4]arene $(\mathbf{1})(7.46 \mathrm{~g}, 17.6 \mathrm{mmol})$, $\mathrm{K}_{2} \mathrm{CO}_{3}(2.49 \mathrm{~g}, 18 \mathrm{mmol}$ ), and 11-bromoundecyl 2-tetrahydropyranyl ether $(11.8 \mathrm{~g}, 35 \mathrm{mmol})$ in $\mathrm{CH}_{3} \mathrm{CN}(300 \mathrm{~mL})$ was refluxed for $48 \mathrm{~h}$ under a dry argon atmosphere. Thesolvent was removed under reduced pressure on a rotary evaporator, and the residue was taken up into $\mathrm{CH}_{2} \mathrm{Cl}_{2}$ (100 mL). The organic phase was washed with $\mathrm{HCl}(1 \mathrm{~N}, 50 \mathrm{~mL})$, demineralized water $(300 \mathrm{~mL})$, and brine (100 mL). Column chromatography $\left(\mathrm{SiO}_{2}, \mathrm{CH}_{2} \mathrm{Cl}_{2}\right)$ afforded 3 (10.18 g, 62\%) as a white solid: $\mathrm{mp} 98-100{ }^{\circ} \mathrm{C}$; FAB $\left(\mathrm{M}+\mathrm{Na}^{+}\right.$956, calc 932.6); ${ }^{1} \mathrm{H}$ NMR $\delta 8.22$ (s, 2H, ArOH), 7.04 $(\mathrm{d}, 4 \mathrm{H}, \mathrm{J}=7.5 \mathrm{~Hz}, \mathrm{~m}-\mathrm{ArH}), 6.91(\mathrm{~d}, 4 \mathrm{H}, \mathrm{J}=7.5 \mathrm{~Hz}, \mathrm{~m}-\mathrm{ArH}), 6.73$ $(\mathrm{t}, 2 \mathrm{H}, \mathrm{J}=7.5 \mathrm{~Hz}, \mathrm{p}-\mathrm{ArH}), 6.63(\mathrm{t}, 2 \mathrm{H}, \mathrm{J}=7.5 \mathrm{~Hz}, \mathrm{p}-\mathrm{ArH}), 4.57$ $(\mathrm{t}, 2 \mathrm{H}, \mathrm{J}=3.5 \mathrm{~Hz}, \mathrm{OCHO}), 4.31$ and $3.37(\mathrm{ABq}, 8 \mathrm{H}, \mathrm{J}=12.9 \mathrm{~Hz}$, $\left.\mathrm{ArCH}_{2} \mathrm{Ar}\right), 3.99\left(\mathrm{t}, 4 \mathrm{H}, \mathrm{J}=6.9 \mathrm{~Hz}, \mathrm{ArOCH}_{2}\right), 3.9-3.3(\mathrm{~m}, 8 \mathrm{H}$, $\left.\mathrm{CH}_{2} \mathrm{OCH}, \mathrm{ArCH}_{2} \mathrm{Ar}\right), 2.1-2.0\left(\mathrm{~m}, 4 \mathrm{H}, \mathrm{CH}_{2} \mathrm{CHO}\right), 1.9-1.3(\mathrm{~m}$, $30 \mathrm{H}, \mathrm{CH}_{2}$ ); ${ }^{13} \mathrm{C}$ NMR $\delta 153.4$ and 152.0 (s, Ar-25,27,26,28), 133.5 and 128.2 (s, Ar-1,3,7,9,13,15,19,21), 128.9 and 128.4 (d, Ar4,6,10,12,16,18,22,24), 125.2 and 118.9 (d, Ar-5,11,17,23), 98.8 (d, OCHO), $76.78\left(\mathrm{t}, \mathrm{ArOCH}_{2}\right), 67.7$ and $62.3\left(\mathrm{t}, \mathrm{CH}_{2} \mathrm{OCH}\right), 31.5$ (t, $\mathrm{ArCH}_{2} \mathrm{Ar}$ ), 30.8, 30.0, 29.8, 29.7, 29.6, 29.5, 26.3, 26.0, 25.5, $19.7\left(\mathrm{t}, \mathrm{CH}_{2}\right)$. Anal. Calc for $\mathrm{C}_{60} \mathrm{H}_{84} \mathrm{O}_{8}$ : C, 77.21; $\mathrm{H}, 9.07$. Found: $\mathrm{C}, 77.24 ; \mathrm{H}, 9.43$.

25,27-Bis[(11-((2-tetrahydropyranyl)oxy)undecyl )oxy]calix[4]arene-crown-6 (4). A mixture of 25,27-bis[(11-((2-tetrahydropyranyl)oxy)undecyl)oxy]calix[4]areneether (3) $(2.35 \mathrm{~g}, 2 \mathrm{mmol})$ and $\mathrm{Cs}_{2} \mathrm{CO}_{3}(2.61 \mathrm{~g}, 8 \mathrm{mmol})$ in $\mathrm{CH}_{3} \mathrm{CN}(600 \mathrm{~mL})$ was gently refluxed for $30 \mathrm{~min}$, after which a sol ution of pentaethyleneglycol ditosylate $(1.32 \mathrm{~g}, 2.4 \mathrm{mmol})$ dissolved in $\mathrm{CH}_{3} \mathrm{CN}(200 \mathrm{~mL})$ was added dropwise. Themi xture was refluxed gently for $72 \mathrm{~h}$ under a dry argon atmosphere. Thesolvent was removed under reduced pressure, and the residue was taken up into $\mathrm{CH}_{2} \mathrm{Cl}_{2}(100 \mathrm{~mL})$. The organic phase was washed with $\mathrm{HCl}(1 \mathrm{~N}, 250 \mathrm{~mL})$, demineralized water $(500 \mathrm{~mL})$, and brine $(100 \mathrm{~mL})$. Column chromatography $\left(\mathrm{SiO}_{2}\right.$, ethyl acetate-hexane 75:25) afforded 4 $(1.4 \mathrm{~g}, 48 \%)$ as a liquid with refractive index $[\alpha]_{D}^{20} 1.5349: \mathrm{FAB}$ $\left(\mathrm{M}+\mathrm{Na}^{+}\right.$1157.4, calc 1134.7); ${ }^{1} \mathrm{H}$ NMR $\delta 7.07(\mathrm{~d}, 4 \mathrm{H}, \mathrm{J}=7.5$ $\mathrm{Hz}, \mathrm{m}-\mathrm{ArH}), 7.01(\mathrm{~d}, 4 \mathrm{H}, \mathrm{J}=7.5 \mathrm{~Hz}, \mathrm{~m}-\mathrm{ArH}), 6.82(\mathrm{t}, 2 \mathrm{H}, \mathrm{J}=$ $7.4 \mathrm{~Hz}, \mathrm{p}-\mathrm{ArH}), 6.76(\mathrm{t}, \mathrm{J}=7.5 \mathrm{~Hz}, 2 \mathrm{H}, \mathrm{p}-\mathrm{ArH}), 4.59(\mathrm{t}, 2 \mathrm{H}, \mathrm{J}=$ $3.5 \mathrm{~Hz}, \mathrm{OCHO}), 3.9-3.4\left(\mathrm{~m}, 40 \mathrm{H}, \mathrm{OCH}_{2}\right), 1.8-1.2\left[34 \mathrm{H}, \mathrm{CH}_{2-}\right.$ (chain)]; ${ }^{13} \mathrm{C}$ NMR $\delta 156.9$ and 156.4 (s, Ar-25,26,27,28), 134.1 and 133.7 (s, Ar-1,3,7,9,13,15,19,21), 129.8 and 129.6 (d, Ar4,6,10,12,16,18,22,24), 122.1 (d, Ar-5,11,17,23), 96.8 (d, OCHO), $71.2,71.1,71.0,70.6,69.9,67.7,62.3,60.4\left(\mathrm{t}, \mathrm{CH}_{2}\right), 37.9\left(\mathrm{t}, \mathrm{ArCH}_{2^{-}}\right.$ Ar), 30.6, 29.8, 29.75, 29.7, 29.6, 29.3, 26.8, 25.8, 25.5, 19.7, 14.2 (t, $\mathrm{CH}_{2} \mathrm{CH}_{2} \mathrm{CH}_{2}$ ).

25,27-Bis[(11-hydroxyundecyl)oxy]calix[4]arene-crown-6 (5) was obtained in analogy with ref 23 in $87 \%$ yield. Column chromatography $\left(\mathrm{SiO}_{2}\right.$, ethyl acetate-dichloromethane $\left.75: 25\right)$ afforded 5 (1.4 g, 85\%) as a white solid: $\mathrm{mp} 116-118{ }^{\circ} \mathrm{C}$; F AB $\left(\mathrm{M}+\mathrm{Na}^{+}\right.$989.8, calc 966.6); ${ }^{\mathrm{H}} \mathrm{H} \mathrm{NMR} \delta 7.08(\mathrm{~d}, 4 \mathrm{H}, \mathrm{J}=7.5 \mathrm{~Hz}$, $\mathrm{m}-\mathrm{ArH}), 7.01(\mathrm{~d}, 4 \mathrm{H}, \mathrm{J}=7.5 \mathrm{~Hz}, \mathrm{~m}-\mathrm{ArH}), 6.8-6.7(\mathrm{~m}, 4 \mathrm{H}, \mathrm{p}-\mathrm{ArH})$, $3.8-3.33\left(\mathrm{~m}, 36 \mathrm{H}, \mathrm{OCH}_{2}\right), 1.6-1.2\left(\mathrm{~m}, 38 \mathrm{H}, \mathrm{CH}_{2}\right) ;{ }^{13} \mathrm{C} \mathrm{NMR} \delta$ 156.9 and 153 (s, Ar-25,26,27,28), 134.1 and 133.8 (s, Ar-1,3,7,9,$13,15,19,21), 129.8$ and 129.6 (d, Ar-4,6,10,12,16,18,22,24), 122.1 (d, Ar-5,11,17,23), 71.1, 70.9, 70.6, 69.9, 63.0 (t, $\mathrm{ArOCH}_{2} \mathrm{CH}_{2}$ ), 37.9 (t, $\left.\mathrm{ArCH}_{2} \mathrm{Ar}\right), 32.8,29.7,29.5,29.3,25.8\left(\mathrm{t}, \mathrm{CH}_{2} \mathrm{CH}_{2}\right)$. Anal. Calc for $\mathrm{C}_{60} \mathrm{H}_{86} \mathrm{O}_{10}$ : C, 74.55; $\mathrm{H}, 8.97$. Found: $\mathrm{C}, 74.38 ; \mathrm{H}, 8.99$.

2-Nitrophenyl octyl ether (NPOE) was synthesized as described elsewhere. ${ }^{24}$ The purity of the compound was checked by gas chromatography.

2.2. Preparation and Purification of Silica Particles Grafted with Calixarene and/or Octadecyl Groups. All

(22) Gutsche, C. D.; I qbal, M. Org. Synth. 1989, 68, 234.

(23) Miyashita, M.; Yoshikoshi, A.; Grieco, P. A.J . Org. Chem. 1977, $42,3772$.

(24) I keda, I.; Tamazaki, H.; Konishi, T.; Okahara, M.J . Membr. Sci. 1989, 46, 113. 
Table 1. Experimental Details for (Co)grafting Reaction in 2-Nitrophenyl Octyl Ether (NPOE)

\begin{tabular}{lcccc}
\hline \multicolumn{1}{c}{ code } & $\begin{array}{c}\text { compound } \\
\mathbf{5}(\mathrm{g})\end{array}$ & $\begin{array}{c}\text { octadecyl } \\
\text { alcohol }(\mathrm{g})\end{array}$ & $\begin{array}{c}\text { NPOE } \\
(\mathrm{mL})\end{array}$ & silica $(\mathrm{g})$ \\
\hline SA11NPOE & & & 20 & 1 \\
SLNPOE & & & 50 & 2 \\
SA11C 18 & & 7 & 25 & 9 \\
SLC $_{18}$ NPOE & & 10 & 25 & 1.48 \\
SLCALIXNPOE & 0.143 & & 50 & 2.1 \\
SA11CALIX & 0.3 & & 25 & 9 \\
SA11CALIXC & 0.3 & 7 & 25 & 9 \\
SLCALIXC $_{18}$ NPOE & 0.4 & 10 & 25 & 1.48
\end{tabular}

glassware was cleaned with aqueous HF (8\%) solution, hot tap water, and doubly distilled water. The chemicals were used as supplied without further purification unless stated otherwise. Dowex 50W $\times 4$ acid ion exchange and Dowex $1 \times 4$ anion exchange resins were regenerated by subsequent rinsing with hot water, methanol, $\mathrm{HCl}(3 \mathrm{~N})$, or $\mathrm{NaOH}(3 \mathrm{~N})$, respectively, and cold demineral ized water until $\mathrm{pH}=6.25$ Thestarting dispersions of bare, uncoated silica spheres were prepared by the Stöber synthesis ${ }^{17}$ or supplied by DuPont (Ludox AS-40). Universal indicator $\mathrm{pH}$ 0-14 (Merck) was used to check thepH of the L udox dispersion. Coating procedures were carried out under a slow flow of nitrogen dried by passing it over $\mathrm{CaCl}_{2}$. Dispersions of coated particles were purified from free organic compounds by centrifugation either for $20 \mathrm{~h}$ in an ultracentrifuge (Beckman $\mathrm{L}-60$ ) in thecase of Ludox particles or for $6 \mathrm{~h}$ in a table centrifuge (Beckman GS-6) in the case of larger Stöber silica spheres. Centrifugation procedures werein most cases repeated four times.

The particles were characterized with transmission electron microscopy (Philips CM 10). ${ }^{13} \mathrm{C}$ CP-MAS NMR spectra were measured on a Varian Unity 400 WB NMR spectrometer. Elemental analysis was performed by Mikroanalytisches Labor Pascher (Remagen, Germany) on silica particles dried for $48 \mathrm{~h}$ at $70{ }^{\circ} \mathrm{C}$ under a nitrogen atmosphere. The colloidal stability of the dispersions in various solvents, that is, the absence of large particle aggregates, was checked visually.

It is important to note that NMR and elemental analysis only detect organic groups on thesilica surface, becausefreemolecules are removed by sedimentation. Suppose, for example, the $\mathrm{n}_{0}$ moles of free molecules and a silica volume fraction $\phi_{\text {disp }}$ are present in a volume $\mathrm{V}$ of dispersion after the grafting procedure. Centrifugation produces a sediment with silica volume fraction $\phi_{\text {sed }}$ and a fraction of the $n_{0}$ moles. This sediment is redispersed in a volume $V$ of pure solvent. After $x$ centrifugation steps the number of free molecules in the sediment is about

$$
\mathrm{n}(\mathrm{x})=\left(1-\phi_{\mathrm{sed}}\right)^{\mathrm{x}}\left(\phi_{\mathrm{disp}} / \phi_{\mathrm{sed}}\right)^{\mathrm{x}} \mathrm{n}_{0}
$$

For random dose-packed spheres the sediment density will be close to $\phi_{\text {sed }}=0.64$. The silica concentrations in the grafting procedures are of the order $\phi_{\text {disp }} \sim 0.01$. One can easily verify that, for $x \geq 3$ sedimentation steps, the amount of unreacted compounds will be negligible.

Particle codes. The following codes are used. SA11 refers to ungrafted Stöber silica spheres, and SL to ungrafted Ludox particles. The solvent in which particles have been refluxed or grafted appears at the end of the code, after the grafting agent(s). For example, SLTEP denotes bare Ludox silica after refluxing in pure triethyl phosphate (TEP), and $\mathbf{S A 1 1 C}_{\mathbf{1 8}^{-}}$ CALIXNPOE is the code for SA11 particles grafted with octadecyl al cohol and compound 5 in NPOE. Theseparticlecodes also appear in Tables 1 and 2, which contain the amounts of reagents used in the grafting procedures.

Silica dispersion in ethanol-ammonia (SA11) was prepared as follows. Freshly distilled tetraethoxysilane $(100 \mathrm{~mL}$, TES, Fluka) was added to a mixture of absolute ethanol ( $2 \mathrm{~L}$, N edalco technical grade) and ammonium hydroxide $(140 \mathrm{~mL}, 25 \%$, Merck). The mixture was stirred for $18 \mathrm{~h}$ at $15.5^{\circ} \mathrm{C}$ in a thermostatic bath. Theobtained particles, coded SA11, havea radius of about $90 \mathrm{~nm}$, as determined by light scattering and particledimensions on transmission electron micrographs, such as in Figure 1. The silica weight concentration of the final SA11 dispersion was $\mathrm{c}=$ $10 \mathrm{~g} / \mathrm{L}$.

(25) Van den Hul, H. J .; Vanderhoff, J . W. J . Colloid Interface Sci. 1968, 28, 337.
Table 2. Experimental Details for (Co)grafting Reaction in Triethyl Phosphate (TEP)

\begin{tabular}{|c|c|c|c|c|}
\hline code & $\begin{array}{c}\text { compound } \\
\mathbf{5}(\mathrm{g})\end{array}$ & $\begin{array}{c}\text { octadecyl } \\
\text { alcohol (g) }\end{array}$ & $\begin{array}{l}\text { TEP } \\
(\mathrm{mL})\end{array}$ & silica (g) \\
\hline SLTEP & & & 50 & 1.6 \\
\hline SLCALIXTEP & $\begin{array}{l}0.2 \\
0.15\end{array}$ & & $\begin{array}{l}70 \\
50\end{array}$ & $\begin{array}{l}2.1 \\
2\end{array}$ \\
\hline $\begin{array}{l}\text { SLC }_{18} \text { TEP } \\
\text { SLCALIXC }_{18} \text { TEP } \\
\text { SA11C }{ }_{18} T \text { TEP } \\
\text { SA11TEP }\end{array}$ & 0.055 & $\begin{array}{r}7 \\
14 \\
3\end{array}$ & $\begin{array}{l}70 \\
50 \\
25 \\
25\end{array}$ & $\begin{array}{l}2.1 \\
2 \\
2 \\
2\end{array}$ \\
\hline SA11CALIXTEP & 0.06 & & 20 & 2 \\
\hline
\end{tabular}

Silica Ludox particles in water (SL) were obtained from aqueous Ludox dispersion, purified by removal of $\mathrm{Na}^{+}$. Sodium ions may cause partide flocculation when particles are transferred to organic solvents. ${ }^{21}$ A Ludox dispersion $(100 \mathrm{~mL}, \mathrm{c}=$ $40 \% \mathrm{w} / \mathrm{w})$ was diluted with demineralized water $(100 \mathrm{~mL})$. The dilute dispersion was passed subsequently through an anion exchangecolumn to removeany $\mathrm{Cl}^{-}$from the system and through an acid cation exchange col umn toremove $\mathrm{Na}^{+}$. During thelatter exchange the $\mathrm{pH}$ of the dispersion drops from 10 to 3 , which is close to the isoelectric point of silica. To prevent flocculation of particles, the $\mathrm{pH}$ of the dispersion is raised to $\mathrm{pH}=10$ with a few drops of ammonia. ${ }^{26}$ The final dispersion, coded SL, has a silica concentration of about $\mathrm{c}=160 \mathrm{~g} / \mathrm{L}$.

Bare Silica in High Boiling Point Solvents (SA11NPOE, SLNPOE, SAIITEP, and SLTEP). Previous to the grafting reactions, the colloidal stability of dispersions (SA11 and $\mathbf{S L}$ ) in NPOE or triethyl phosphate (TEP) was checked. This was done by performing blank experiments by treating the particles in NPOE or TEP without any organic grafting agents. (This also gives reference particles for comparison with grafted colloids, for example, in solid state NMR; see section 2.4.) Ludox silica particles have been transferred from water to ethanol and then gradually to other polar solvents by distillation. ${ }^{26}$ Using the same procedure, Stöber silica spheres were transferred from ethanol to NPOE. The procedure was typically as follows: A silica dispersion (10 mL, SA11 or SL) was transferred to pure ethanol by distilling water and ammonia. During the distillation, propanol $(10 \mathrm{~mL})$ and ethanol $(100 \mathrm{~mL})$ were added to remove all water from thesystem. When the distillatehad therefractive index of pure ethanol, distillation was stopped. The particles in pure ethanol were added gradually to pure NPOE (without coating agent, see Tables 1 and 2 ), removing gently the ethanol by distillation. After all ethanol was distilled, the temperature was raised to $140-160^{\circ} \mathrm{C}$ and kept at this valuefor 4 days under dry nitrogen. The dispersions coded SA11NPOE, SLNPOE, SA11TE $P$, and SLTEP were sedimented and redispersed five times to transfer particles again to pure ethanol.

Octadecyl Grafting of Silica (SA11C ${ }_{\mathbf{1 8}}$ NPOE, SLC 18 $_{\mathbf{1}}$ NPOE, SA11C $_{\mathbf{1 8}}$ TEP, and SLC $\mathbf{~}_{\mathbf{1 8}}$ TEP). Procedures for coating silica particles with alkyl chains are well documented.18,19 The esterification reaction between $\mathrm{SiOH}$ groups on thesilica surface and the hydroxyl group of octadecyl alcohol takes place at high temperature $\left(\sim 180^{\circ} \mathrm{C}\right)$ in molten octadecyl al cohol. I n our work, grafting of the alcohol on the silica surface is performed in a solvent with a high boiling point (NPOE or TEP). Theprocedure was typically asfollows. A dispersion of Ludox particles or Stöber silica spheres in ethanol (prepared as described above) was added to a solution of an excess of octadecyl alcohol in NPOE or TEP. From the mixture, the ethanol was gradually removed by distillation. After all the ethanol was distilled, themixture was stirred at $140-160^{\circ} \mathrm{C}$ for 4 days under dry nitrogen. Thepartides

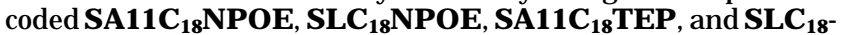
TEP were sedimented and redispersed five times to transfer them to cyclohexane.

Calix[4]arene Grafting of Silica (SA11CALIXNPOE, SLCALIXNPOE, SA11CALIXTEP, and SLCALIXTEP). A dispersion of particles in pure ethanol was added to a solution of 25,27-bis[(11-hydroxyundecyl)oxy]calix[4]arene-crown-6 (5) (see Tables 1 and 2) in NPOE or TEP, removing gently the ethanol by distillation. After all ethanol was distilled, the mixture was

(26) Pathmamanoharan, C.; Philipse, A. P. J . Colloid Interface Sci. 1994, 165, 519.

(27) Bax, A.; Davis, D. G. J . Magn. Reson. 1985, 65, 355. 
Table 3. Elemental Analysis Results ${ }^{a}$

A. Grafted Ludox Silica

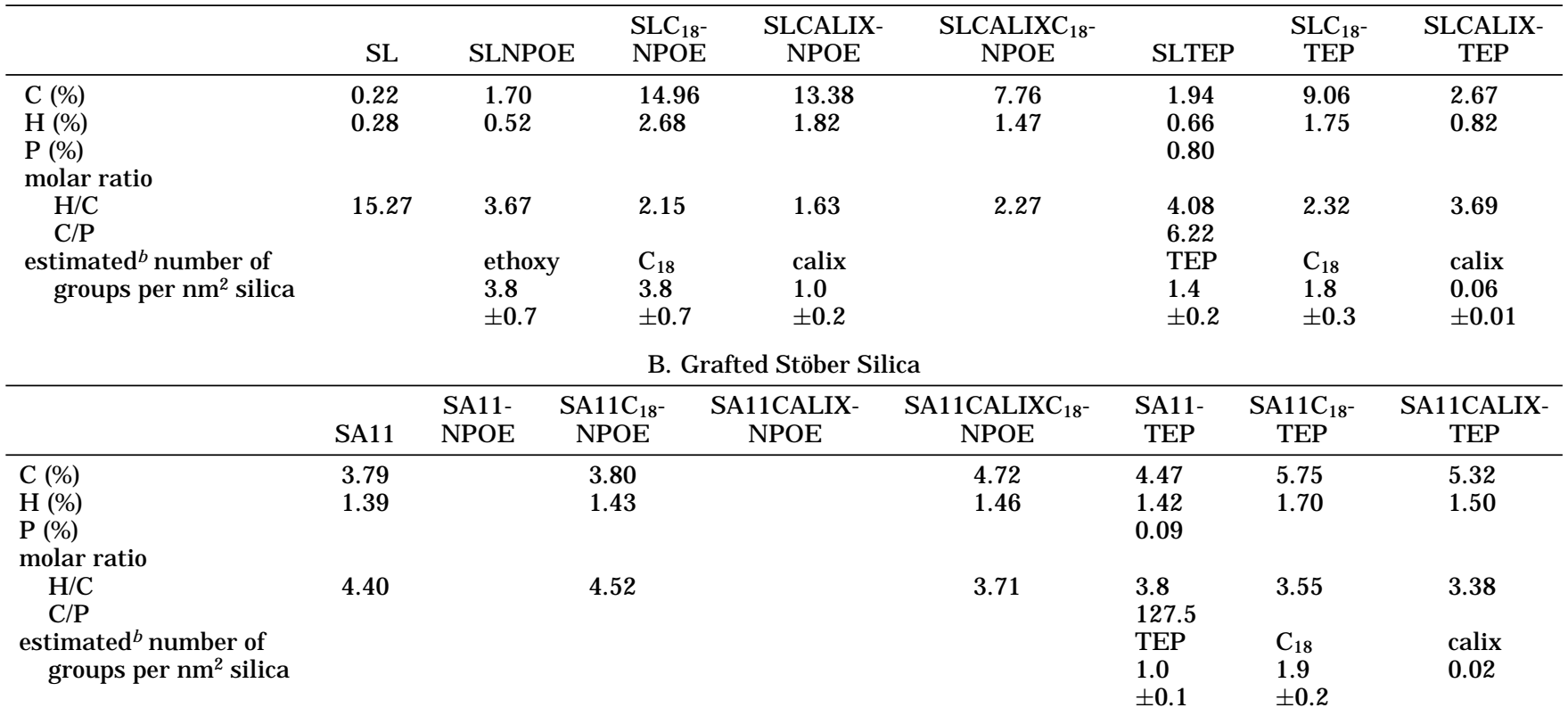

a Particles were dried at $70^{\circ} \mathrm{C} / 1$ atm under nitrogen with a weight loss in the range $0.5-5 \%$. ${ }^{b}$ Uncertainties are mainly dueto the choice of the size of the SL particles and/or the amount of TEP which is present on the silica.

stirred at $145-160^{\circ} \mathrm{C}$ for 4 days under dry nitrogen. Centrifugation was carried out three times to transfer the particles to chloroform. We note that a grafting time of 4 days is required torender theparticles dispersiblein chloroform. When a sample of the reaction mixture is added to chloroform after 2-3 days, flocculation occurs, indicating that the surface coverage is still too low.

Calix[4]areneOctadecyl Cografting of Silica (SA11CALIXC $\mathbf{X 1 8}_{\mathbf{1 8}}$ NPOE, SLCALIXC ${ }_{18}$ NPOE, and SLCALIXC ${ }_{18}$ TEP). Performing the coating procedurein NPOE and TEP allows the possibility of coating the silica particles successively with 25,27-bis[(11hydroxyundecyl)oxy]calix[4]arene-crown-6 (5) and octadecyl alcohol. The quantities used in these reactions are presented in Tables 1 and 2. The procedure was typically as follows: A dispersion of SL $(1.48 \mathrm{~g})$ in pure ethanol $(10 \mathrm{~mL})$ was added to a solution of $\mathbf{5}(0.4 \mathrm{~g})$ in NPOE or TEP $(50 \mathrm{~mL})$. The ethanol was distilled, and theresulting dispersion in NPOE or TEP washeated at $145-160^{\circ} \mathrm{C}$ under dry nitrogen. After 2 days octadecyl al cohol was added, keeping the dispersion at $145-160{ }^{\circ} \mathrm{C}$ for 2 more days. The final dispersion was sedimented five times and redispersed in chloroform.

2.3. Complexation Experiments. Complexation experiments of free 25,27-bis[(11-hydroxyundecyl)oxy]calix[4]arenecrown-6 ether or SLCALIXNPOE in deuterated chlor oform were performed as follows. A solution of compound $\mathbf{5}$ in $\mathrm{CDCl}_{3}$ or silica dispersion SLCALIXNPOE in chloroform $(2 \mathrm{~mL})$ and a saturated aqueous solution of $\mathrm{CsCl}(2 \mathrm{~mL})$ were gently shaken for 1 week. The organic layer was separated and investigated with ${ }^{1 H}$ NMR. 11,13

2.4. MAS NMR. ${ }^{13} \mathrm{C}$ CP-MAS spectra ${ }^{28}$ were obtained with a Varian U nity 400WB N MR spectrometer equipped with a broadband CP-MAS probe head. The $90^{\circ}$ pulselengths for ${ }^{13} \mathrm{C}$ and ${ }^{1} \mathrm{H}$ were $3.5 \mu \mathrm{s}$. The samples were spun at $6000 \mathrm{~Hz}(5 \mathrm{~mm} \mathrm{ZrO}$ rotors), and the cross-polarization times were $1 \mathrm{~ms}$. Typically 8000 transients were acquired with a relaxation delay time of $5 \mathrm{~s}$. Hexamethylbenzene was used to optimize experimental parameters and as an external chemical shift reference. Solid state ${ }^{31} \mathrm{P}$ MAS NMR spectra were obtained at a spinning rate of $3000 \mathrm{~Hz} . \mathrm{H}_{3} \mathrm{PO}_{4}(85 \%)$ was used as a chemical shift reference. High-resolution ${ }^{1} \mathrm{H}$ NMR spectra of silica dispersions were obtained by spinning theliquid sample at the magic angleat ca. $800-2000 \mathrm{~Hz}$ (in the same probe head which was used for the solid stateCP experiments). Tofacilitatequantitativeevaluation of the ${ }^{1} \mathrm{H}$ MAS NMR spectra, a relaxation delay of $5 \mathrm{~s}$ was used. TOCSY (MLEV17) experiments ${ }^{27}$ under magic angle spinning

(28) Stejskal, E. O.; Memory, . D. High Resolution NMR in theSolid State, Fundamentals of CP/ MAS; Oxford University Press: 1994. conditions wereperformed with mixing times of $35 \mathrm{~ms}$, and TPPI 29 was used for signal accumulation in the $t_{1}$ dimension. The 1D and $2 \mathrm{D}{ }^{1} \mathrm{H}$ MAS spectra were recorded via the ${ }^{1} \mathrm{H}$ decoupler channel; the broad-band ("observe") channel was tuned tothe ${ }^{2} \mathrm{H}$ frequency and employed for ${ }^{2} \mathrm{H}$ field locking.

2.5. Light Scattering. Light scattering was used to determinethesize of particles or particleaggregates in thedispersion. Dynamiclight scattering (laser wavelength $\lambda=488 \mathrm{~nm}$ ) on dilute (c $<1 \mathrm{~g} / \mathrm{L}$ ), dust-freesilica dispersions was performed as described elsewhere. ${ }^{30,31}$ Measurements were done at various scattering angles $\theta$, i.e. at various scattering vectors $K=(4 \pi \mathrm{n} / \lambda) \sin (\theta / 2)$, with $n$ the refractiveindex of the solvent. A diffusion coefficient $D_{0}$ was obtained from the initial slope of the intensity autocorrelation function using cumulant analysis. ${ }^{30,31}$ A hydrodynamic particle radius $R_{h}$ was obtained from the Stokes-Einstein equation $\mathrm{D}_{0}=\mathrm{k}_{\mathrm{B}} \mathrm{T} / 6 \pi \eta \mathrm{R}_{\mathrm{h}}$, with $\eta$ the solvent viscosity and $\mathrm{k}_{\mathrm{B}} \mathrm{T}$ thethermal energy. Static light scattering measurements were performed with a Fica-50 photometer, and scattering intensity profiles were analyzed using the Guinier approximation. ${ }^{3}$

2.6. Electrophoresis. To determine the sign of any (net) surfacechargeon grafted particles, beforeand after complexation, thefollowing simple, qualitativeexperiment was performed. Two electrodes, connected to a $4.5 \mathrm{~V}$ battery, were immersed in a stagnant silica dispersion in a closed vessel. Any migration of colloids to an electrode leads to silica deposition on the electrode surface. The method was checked for aqueous dispersion of negatively charged, bare silica particles and positively charged boehmite $(\mathrm{AlOOH})$ colloids which produced clearly visi bledeposits on a time scale of minutes to hours.

\section{Results and Discussions}

3.1. Synthesis and Properties of 25,27-Bis[(11hydroxyundecyl)oxy]calix[4]arene-crown-6 (5). Compound $\mathbf{5}$ was specifically designed for coupling a calix[4]arene-crown-6 group to a silica surface via its hydroxyl groups. The (elemental) analysis results in section 2.1 show that the reaction scheme as depicted in Figure 2 indeed yields compound $\mathbf{5}$. We note that $\mathbf{5}$ has the 1,3 alternate conformation, as in the other alkylated calix-

(29) Marion, D.; Wuethrich, K. Biochem. Biophys. Res. Commun. $1983,113,967$.

(30) Berne, B. J .; Pecora, R. Dynamic Light Scattering; Wiley: New York, 1976.

(31) Kops-Werkhoven, M. M.; Fijnaut, H. M. J . Chem. Phys. 1981, 74, 1618. 


\section{Synthesis}
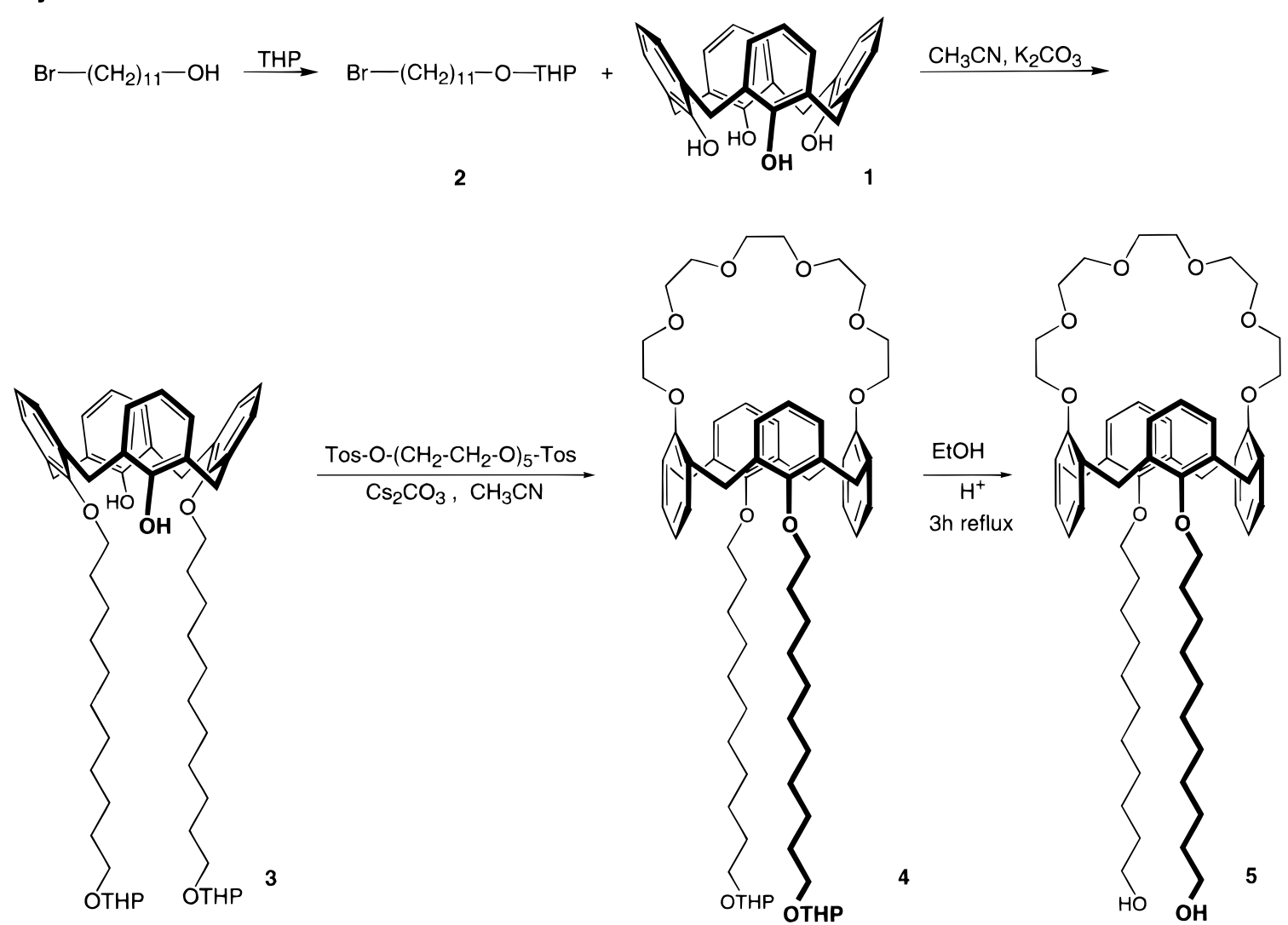

Figure 2. Synthesis scheme for the calixarene derivate 5, having two pendant alkyl chains with terminal OH groups by which it can be attached to a silica particle.

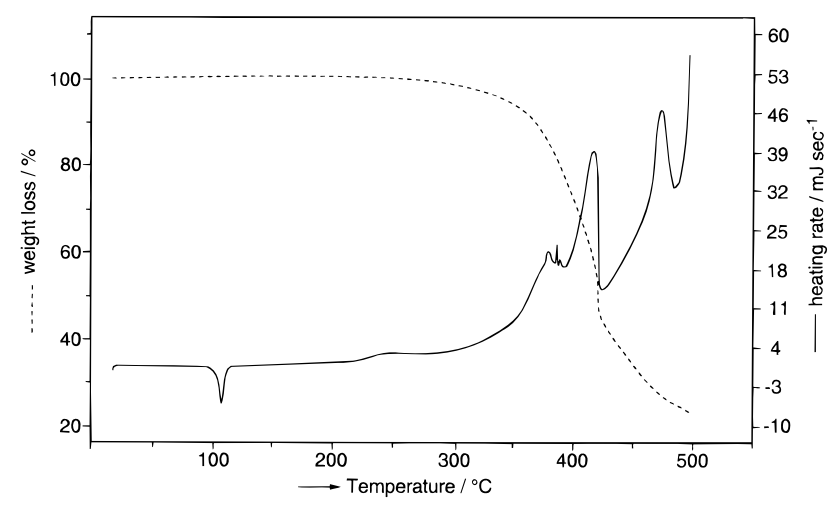

Figure 3. Differential scanning calorimetry results for compound $\mathbf{5}$, showing that it is stable at the grafting temperature of $160{ }^{\circ} \mathrm{C}$.

[4]arene-crown-6 compounds synthesized by alkylation in the presence of salt. ${ }^{12,14}$

The grafting of $\mathbf{5}$ onto silica particles takes place at a temperaturein therange $140-160^{\circ} \mathrm{C}$. No decomposition of $\mathbf{5}$ will take place at this temperature. The differential scanning calorimetry results in Figure 3 show that 5 decomposes only above $250^{\circ} \mathrm{C}$.

The Langmuir-Blodgett (LB) isotherms of compound 4 reveal a monolayer on water corresponding to an area of about $1 \mathrm{~nm}^{2}$ per molecule. This area gives an indication of the silica surface per calix group, in the case the calix molecules would form a dense (mono)layer on silica particles. This point is further discussed in section 3.7.

In compound $\mathbf{4}$ the hydroxyl groups are blocked by tetrahydropyranyl groups. In compound $\mathbf{5}$ unprotected, free $\mathrm{OH}$ groups are present. Their presence is also manifested by their interaction with the water surface directly after spreading. ${ }^{32}$
3.2. Bare Silica Particles in High Boiling Point Solvents. Silica particles were generally stable (i.e. no visible flocs) in mixtures of NPOE or TEP and ethanol and also at elevated temperatures. Removal of ethanol by distillation generally resulted in a stable dispersion of silica particles. The concentration of the dispersion, nevertheless, is a critical factor for the stability of Ludox particles in pure NPOE. The bare Ludox particles seem to be stable in NPOE only at very low concentrations. At the concentration used in the coating procedure, sometimes space-filling gels were formed. By diluting these gels with NPOE or ethanol, a stable dispersion was regenerated, as judged by visual inspection. However, small aggregates may still be present (see section 3.6).

No flocculation was observed after stirring the dispersions in NPOE or TEP at $145-160{ }^{\circ} \mathrm{C}$ for 4 days. The resulting SA11NPOE and SLNPOE particles show the same colloidal stability (Table 4) in various solvents as the initial SA11 and SL dispersions.

This result, together with the fact that in solid state N MR (F igures 4B and 5B) noaromatic signal s are present, indicates that NPOE does not adsorb onto the silica surface. (In contrast, ${ }^{31}$ P MAS NMR spectra clearly reveal the presence of TEP on particles grafted in TEP.) The weak aliphatic resonances which appear in the ${ }^{13} \mathrm{C} \mathrm{CP}$ MAS spectrum (Figure 4B) of SLNPOE dispersions are also intriguing. These resonances can be assigned to ethoxy moi eties attached to the silica surface. Possibly, during the thermal treatment the adsorbed ethanol and propanol reacted with $\mathrm{SiOH}$ from thesilica surface. These findings areconfirmed by elemental analysis (section 3.7).

3.3. Octadecyl-Grafted Silica Particles. NPOE is a polar organic solvent with a high boiling point in which bare particles are fairly stable (see section 3.2). This 
Table 4. Colloidal Stability of Silica Dispersions in Various Solventsa

\begin{tabular}{|c|c|c|c|c|c|c|c|c|}
\hline \multirow[b]{2}{*}{ silica } & \multicolumn{8}{|c|}{ stability in given solvent } \\
\hline & $\mathrm{H}_{2} \mathrm{O}$ & ETOH & THF & DMF & NPOE & $\mathrm{CHCl}_{3}$ & $\mathrm{C}_{7} \mathrm{H}_{8}$ & $\mathrm{CHX}$ \\
\hline $\begin{array}{l}\text { SAIISL } \\
\text { SAIINPOE } \\
\text { SLNPOE }\end{array}$ & $\begin{array}{l}\mathrm{S} \\
\mathrm{S} \\
\mathrm{S}\end{array}$ & $\begin{array}{l}\mathrm{S} \\
\mathrm{S} \\
\mathrm{S}\end{array}$ & $\begin{array}{l}S \\
S \\
S\end{array}$ & & $\begin{array}{l}\text { FS } \\
\text { FS } \\
\text { FS }\end{array}$ & $\begin{array}{l}\text { IS } \\
\text { IS } \\
\text { IS }\end{array}$ & $\begin{array}{l}\text { IS } \\
\text { IS } \\
\text { is }\end{array}$ & $\begin{array}{l}\text { IS } \\
\text { IS } \\
\text { IS }\end{array}$ \\
\hline 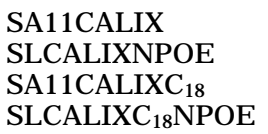 & $\begin{array}{l}\text { IS } \\
\text { IS } \\
\text { IS } \\
\text { is }\end{array}$ & $\begin{array}{l}\text { IS } \\
\text { IS } \\
\text { IS } \\
\text { IS }\end{array}$ & $\begin{array}{l}\text { IS } \\
\text { IS } \\
\text { IS } \\
\text { IS }\end{array}$ & $\begin{array}{l}\text { FS } \\
\text { FS } \\
\text { FS } \\
\text { FS }\end{array}$ & $\begin{array}{l}\text { FS } \\
\text { FS } \\
\text { FS } \\
\text { FS }\end{array}$ & $\begin{array}{l}\mathrm{S} \\
\mathrm{S} \\
\mathrm{S} \\
\mathrm{S}\end{array}$ & $\begin{array}{l}\text { IS } \\
\text { IS } \\
\text { IS } \\
\text { IS }\end{array}$ & $\begin{array}{l}\text { IS } \\
\text { IS } \\
\text { IS } \\
\text { IS }\end{array}$ \\
\hline $\begin{array}{l}\mathrm{SA}_{11 C_{18}} \\
\mathrm{SLC}_{18}{ }^{\mathrm{NPOE}}\end{array}$ & $\begin{array}{l}\text { IS } \\
\text { IS }\end{array}$ & $\begin{array}{l}\text { IS } \\
\text { IS }\end{array}$ & $\begin{array}{l}\text { IS } \\
\text { IS }\end{array}$ & $\begin{array}{l}\mathrm{S} \\
\mathrm{S}\end{array}$ & $\begin{array}{l}\mathrm{S} \\
\mathrm{S}\end{array}$ & $\begin{array}{l}S \\
S\end{array}$ & $\begin{array}{l}\mathrm{S} \\
\mathrm{S}\end{array}$ & $\begin{array}{l}\mathrm{S} \\
\mathrm{S}\end{array}$ \\
\hline
\end{tabular}

a $\mathrm{S}=$ stable; $\mathrm{FS}=$ stable for a short period of time; IS = instable.

\section{$13 \mathrm{C}$ Solid State NMR SL}

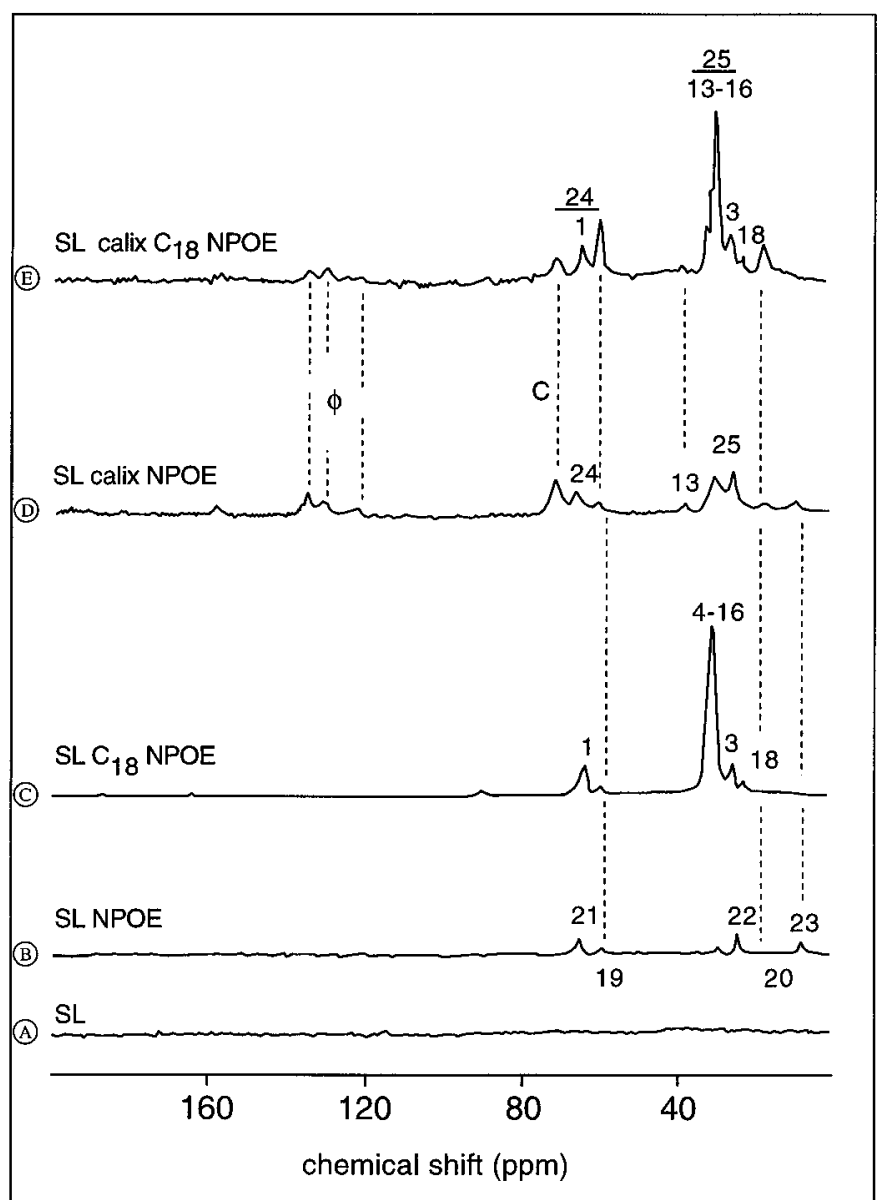

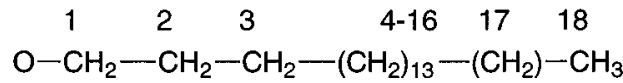

1920

$\mathrm{O}-\mathrm{CH}_{2}-\mathrm{CH}_{3}$

$\begin{array}{lll}21 & 22 & 23\end{array}$

$\mathrm{O}-\mathrm{CH}_{2}-\mathrm{CH}_{2}-\mathrm{CH}_{3}$

Figure 4. ${ }^{13} \mathrm{C}$ CP-MAS spectra and shift assignments for silica ludox (SL) particles grafted in 2-nitrophenyl octyl ether (NPOE): (A) starting SL particles, dried from water; (B) SL particles transferred via ethanol to NPOE and kept in pureNPOE under grafting conditions (4 days of stirring at $160^{\circ} \mathrm{C}$ ); (C) SL particles grafted with octadecyl chains in NPOE; (D) cal ix-grafted silica particles in NPOE; (E) SL particles cografted with cal ixarenes and octadecyl chains in NPOE. Samples were, before drying, purified from unreacted grafting agents by extensive sedimentation procedures, so signals are due to organic moieties on the silica surface.

suggests that NPOE and also TE P are suitable media for grafting alcohols onto silica, especially when one has to use small quantities of expensive compounds. (The conventional grafting procedure for octadecyl alcohol requires a large amount of al cohol to form a melt in which silica is dispersed. ${ }^{18}$ ) First, we verified whether the esterification reaction between silica and an al cohol indeed occurs in these solvents (reaction conditions as described in section 2.2).

In the ${ }^{13} \mathrm{C}$ CP-MAS spectrum of octadecyl-grafted particles (SL $\mathbf{C}_{\mathbf{1 8}} \mathbf{N P O E}$ ) the signals of long-chain alkoxy moieties can beclearly discerned (F igure 4C). Theposition and intensity ratios of these resonances are in accordance with data obtained for alkoxysilane-based silica particles coated with octadecyl al cohol. ${ }^{33}$ Besides the presence of theoctadecyl chains, the ${ }^{13}$ C CP-MAS spectra of SA11C $\mathbf{~ 1 8}^{-}$ NPOE (Figure 5C) also show the presence of propoxy and ethoxy moieties. The latter can al so be detected before grafting (Figure5A) and havebeen trapped in the particles during the Stöber synthesis of SA11.33 The propoxy moieties are most likely trapped in small pores inside the interior of the SA11 particles during thegrafting procedure (vide supra). (It is possible that during the procedure some extra ethoxy moieties are absorbed in the pores of SA11, but these cannot be distinguished from the ethoxy al ready present in the bare particles). The absence of

(33) Van Blaaderen, A.; Kentgens, A. P. M.J . Non-Cryst. Solids 1992, 149, 161. 
13C Solid State NMR SA 11
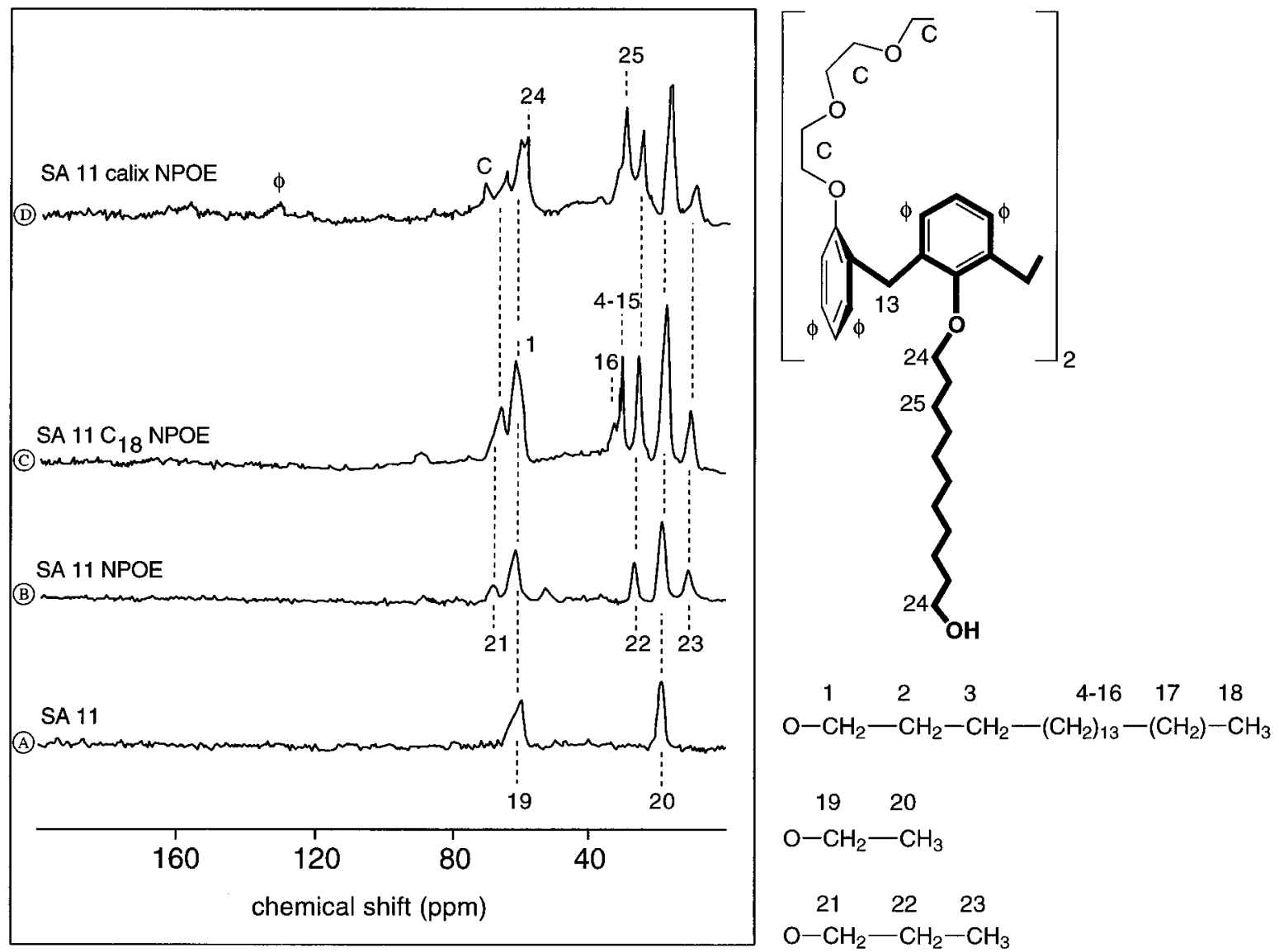

Figure 5. ${ }^{13} \mathrm{C}$ CP-MAS spectra and shift assignments of Stöber silica (SA) spheres grafted in 2-nitrophenyl octyl ether (NPOE): (A) starting spheres dried from ethanol-ammonia; (B) spheres transferred to NPOE and kept in pure NPOE under grafting conditions (4 days of stirring an $160^{\circ} \mathrm{C}$ ); (C) silica spheres grafted with octadecyl alcohol and (D) calixarene groups. Signals are only due to organic molecules on the silica surface.

any aromatic signals in ${ }^{13} \mathrm{C}$ CPMAS spectra excludes the presence of NPOE absorbed to the silica surface of SA11. In the ${ }^{13} \mathrm{C}$ CP-MAS spectra of SLC ${ }_{\mathbf{1 8}}$ NPOE al so signals from ethoxy and propoxy are present, but these are small compared tothe signals of theoctadecyl chains. A similar picture is obtained when the octadecyl grafting is performed in triethyl phosphate (TEP).

The presence of alkyl chains on silica particles is also demonstrated by the carbon content from elemental analysis (see Table 3) and the colloidal stability of the dispersions in various solvents (see Table 4).

3.4. Calix-Grafted Silica. The esterification reaction between the silica surface and the cal ix[4]arene-crown- 6 with $\mathrm{HO}$-terminated alkyl chains is similar tothereaction of octadecyl alcohol with silica particles. The presence of 5 on the SLCALIXNPOE, SA11CALIXNPOE, and SLCALIXTEP particle surfaces is evident from the presence of several resonances in the aromatic regions (Figure 4D and 5D) of the ${ }^{13} \mathrm{C} \mathrm{CP}$ MAS spectra. Further support is found in the resonance at 71 ppm, which can beascribed tothe crown methylene carbons. Alsoin these ${ }^{13} \mathrm{C}$ CP MAS spectra significant (SA11CALI XNPOE) or trace (SLCALI XNPOE) amounts of ethoxy and propoxy moieties can be observed (whose origin was described in the previous section). The ${ }^{31}$ P MAS NMR spectrum of SLCALIXTEP reveals the presence of TEP.

NMR characterization of silica particles grafted with organic species has been limited to the observation of the ${ }^{13} \mathrm{C}$ nucleus. The small natural abundance and low gyromagnetic ratio of this nucleus seriously hamper the observation of surface species. Though the ${ }^{1} \mathrm{H}$ nucleus has almost $100 \%$ natural abundance and a high gyro- magneticratio, its observation in thesolid stateis impeded by strong homonuclear dipolar couplings (due to immobilization of the spin system) which lead to very broad signals. When calixarene-grafted SL particles (SLCALIXNPOE) are dispersed in $\mathrm{CDCl}_{3}$, however, some broad signals can be discerned in the aliphatic region of the ${ }^{1} \mathrm{H}$ NMR spectrum. Apparently, the motion of the grafted particles in the dispersion is fast enough to quench the dipolar couplings significantly. A further reduction of the ${ }^{1} \mathrm{H}$ line widths can be attained by spinning the dispersion at the magic angle at a rate of $800-1000 \mathrm{~Hz}$. The ${ }^{1 H}$ NMR lines can now unambiguously be assigned tografted species. Themain effect of magic-anglespinning is theremoval of line-broadening effects duetosl ow motion of surfacespecies and/or fiel d discontinuities near thesilica surface. ${ }^{20,21}$ Compared to the ${ }^{13} \mathrm{C}$ CP-MAS spectra of the solid particles the ${ }^{1} \mathrm{H}$ NMR MAS spectrum (Figure $6 A$ ) of the dispersion shows much better resolution and sensitivity. One other advantage which should be mentioned is that the ${ }^{1} \mathrm{H}$ MAS spectra areacquired by direct excitation (Bloch decay) whereas ${ }^{13} \mathrm{C}$ solid statespectra requirecrosspolarization (CP) in order to yield sufficient sensitivity. Cross-polarized spectra do not lend themselves for quantitative analysis, however, in contrast with Bloch decay spectra (as long as caution is exerted with the choice of proper relaxation delays). No traces of other surfaceabsorbed species can beobserved in the ${ }^{1} \mathrm{H}$ MAS spectrum.

The sensitivity and resolution of the ${ }^{1} \mathrm{H}$ MAS NMR experiment are sufficient to facilitate a so-called homonuclear TOCSY experiment. In the two-dimensional homonuclear TOCSY (or HOHAHA) experiment, connectivities can be observed between J -coupled spins. These 

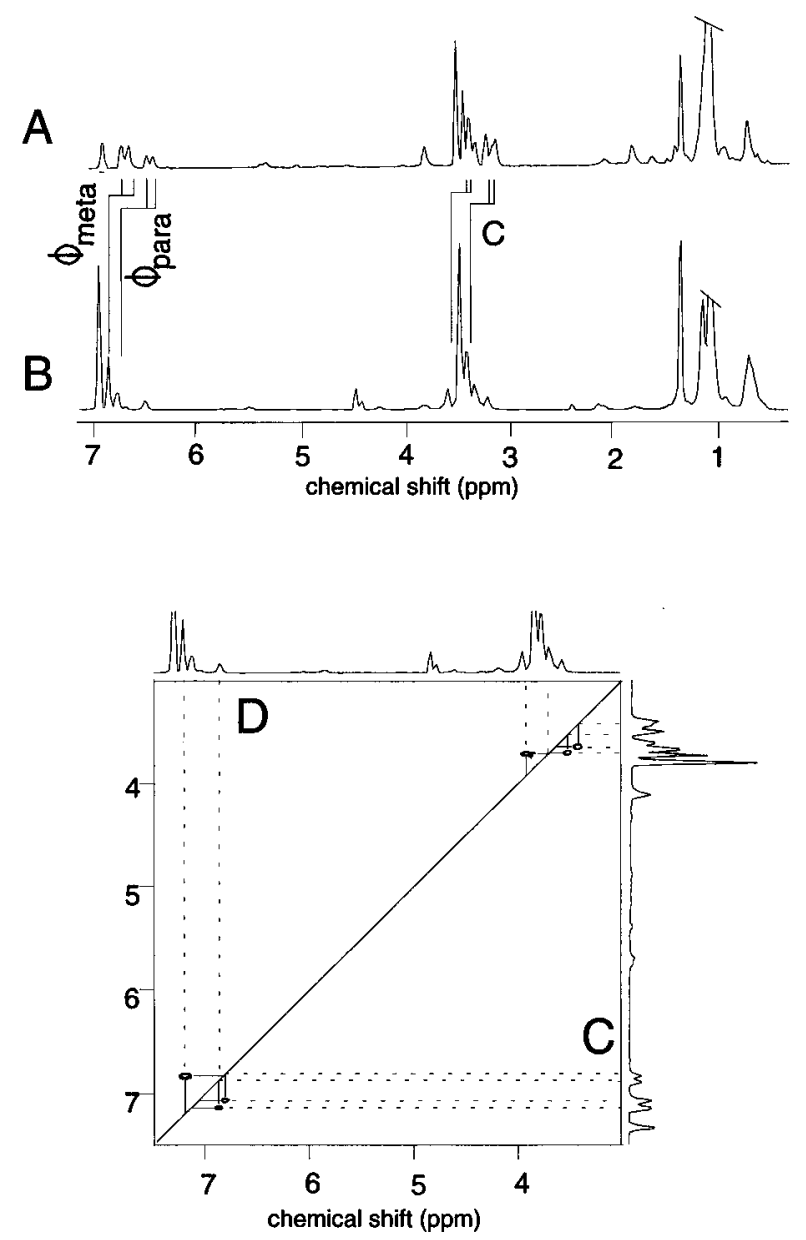

Figure 6. (A) ${ }^{1} \mathrm{H}$ MAS spectrum of SLCALIXNPOE dispersed in $\mathrm{CDCl}_{3}$. Assignments of aromatic and crown protons have been indicated. (B) ${ }^{1} \mathrm{H}$ MAS spectrum of a dispersion of SLCALIXNPOE upon complexation with $\mathrm{Cs}^{+}$. Complexationinduced shifts have been indicated by straight lines. In parts $\mathrm{C}$ and D twoTOCSY spectra are combined. Below the diagonal (C) the TOCSY spectrum is presented which is recorded under the same conditions as for the ${ }^{1} \mathrm{H}$ MAS spectrum in part $A$ (uncomplexed dispersed SLCALIXNPOE). Abovethediagonal (D) the TOCSY spectrum is presented of dispersed SLCALIXNPOE complexed with $\mathrm{Cs}^{+}$. The J -correlated connectivities indicated in the TOCSY spectra confirm the unambiguous assignments made in parts $A$ and $B$.

through-bond connectivities helpin making(or supporting) assignments in complicated spin systems. In Figure 6B the ${ }^{1} \mathrm{H}$ MAS TOCSY spectrum is shown of a dispersion of SLCALIXNPOE in $\mathrm{CDCl}_{3}$. The observed through-bond connectivities are in accordancewith thespectral positions presented for the free species; see section 2.1. The connectivity pattern observed between minor resonances reveals the presence of traces of NPOE in the samples (approximately 10\%).

3.5. Calix-Octadecyl-Cografted Silica Particles. Cografting of silica particles with calix and octadecyl was expected to influence the properties of the dispersions. Surprisingly SLCALIXC $\mathbf{~}_{\mathbf{1 8}}$ NPOE and SA11CALI XC $\mathbf{1 8}_{\mathbf{1 8}}$ NPOE are acting in various solvents similar to silica particles coated only with calixarene. This could imply that octadecyl chains are not grafted on the silica surface for steric hindrance reasons. However, the presence of both octadecyl and $\mathbf{5}$ on the cografted Ludox particles (SLCALIXC ${ }_{18}$ NPOE) is demonstrated by the ${ }^{13} \mathrm{C}$ CP-MAS spectrum in Figure 4E. The unfavorable surface-tovolume ratio for the SA11 particles impedes the observation of ${ }^{13} \mathrm{C}$ nuclei by the CP-MAS experiment, but the ${ }^{1} \mathrm{H}$ MAS NMR experiment clearly shows the presence of $\mathbf{5}$ and octadecyl species on their surface.
3.6. Colloid Stability and Light Scattering. The stability behavior of the various colloids is summarized in Table 4. Some noteworthy results are the following. TheStöber silica (SA11) spheres modified with cal ixarene in NPOE have a much better colloidal stability than the Ludox (SL) particles. Nogelation takes placewhen SA11 spheres are transferred by distillation from ethanol to pure NPOE, in contrast to SL particles. Sediments of SA11CALIXNPOE particles redisperse easily in chloroform and dimethylformamide. They flocculate in cyclohexane and ethanol. Remarkably the flocs in ethanol, and also stable suspensions in chloroform, can be dried and redispersed in chlor oform to nonaggregated particles. The silica spheres (SA11CALIXNPOE) grafted with $\mathbf{5}$ have a long-term stability in chloroform: no aggregates were visible even after 8 months. Because of their size, the spheres settle eventually under the influence of gravity. In that case the dispersion can be easily homogenized by a few minutes of ultrasonication.

TheStöber silica (SA11) spheres grafted with octadecyl alcohol in NPOE show thesamebehavior as silica spheres grafted in an octadecyl alcohol melt:18,19 they form stable dispersions, in apolar solvents such as cyclohexane, and can also be redispersed after drying. The dynamic light scattering results for all modified Stöber silica spheres confirm that aggregation of particles is absent: diffusion coefficients of coated particles yiel d hydrodynamic radii which are the sameas for theinitial silica spheres (radius $90 \mathrm{~nm}$ ) in ethanol-ammonia, as prepared by the Stöber synthesis.

The Ludox particles modified in NPOE show no visible signs of flocculation. The dispersity of grafted Ludox in various solvents follows the same trend as for grafted Stöber spheres mentioned above (see Table 4). Lightscattering results, however, indicate that all Ludox systems contain small particleaggregates when a coating reaction has been performed. Weobserved that uncoated Ludox particles tend to form a gel when transferred to NPOE. The gel disappears upon dilution and (or) mechanical stirring. Very likely small aggregates remain present which are subsequently coated.

Light-scattering measurements on Ludox particles in TEP (before, during, and after a coating procedure) yield reproducibly the same radius of about $15 \mathrm{~nm}$ expected for nonaggregated, freely diffusing colloids, in contrast tothe results for Ludox particles in NPOE. So neither TEP nor the coating procedure destroys the colloidal stability of the Ludox particles. The sedimentation procedure to remove unreacted compounds, however, can induce aggregation in the case of SLCALIXTEP. Upon redispersion of calixarene-Ludox sediments in chloroform, aggregates remain present and no reliable light-scattering measurements are possible. The compressed sediments of SLC ${ }_{18}$ TEP Ludox particles redisperse easily to free particles in cyclohexane and chloroform.

3.7. Elemental Analysis. Theformer sections clearly demonstrate the presence of organic layers of compound 5 and/or octadecyl chains on silica particles. The layers are firmly attached to the silica cores. They also seem to bein general quitedenseand fairly resistant tohydrolysis. In an illustrative experiment we stirred grafted silica particles in an aqueous sodium hydroxide solution ( $\mathrm{pH}=$ 12.6). Theidea wasto(partly) dissolvethesilica particles and/or hydrolyze the $\mathrm{Si}-\mathrm{O}-\mathrm{C}$ bonds by which grafting agents are linked to the silica. Any organic groups were extracted from the aqueous solution with methylene chloride. However, even after several weeks of stirring only minute amounts of extracted organic groups could be detected by NMR. This shows that the grafting layer is indeed quite stable against hydrolysis. We observed, however, that particles coated in TEP are less resistant 
to hydrolysis than particles grafted in NPOE. This suggests that hydrolysis of thecovalently linked phosphate (esters) preferentially takes place.

To gain more insight in grafted layers, we consider the results of elemental analysis, summarized in Table 3, starting with bare Ludox SL particles, going from left to right in Table 3A.

Grafted L udox Particles. TheSL particles contain some carbon, which may be due to a contamination with pol yelectrolytes ${ }^{25}$ from the resin used to remove $\mathrm{Na}^{+}$ions. The SLNPOE particles contain more carbon, reflecting the presence of ethoxy or propoxy groups, as indicated by the NMR results. (Indeed, if the carbon would only stem from NPOE, for which $\mathrm{H} / \mathrm{C}=1.5$, the measured $\mathrm{H} / \mathrm{C}$ ratio would have been smaller.) The carbon content is equivalent to $3.8 \pm 0.7$ ethoxy groups per square nanometer of silica.

The SL $_{\text {18 }}$ NPOE colloids havea ratioH/C $=2.15$, which is close to the value of 2 for octadecyl chains. (The difference is dueto protons fromalkoxy groups or silanol.) Remarkably, the elemental composition is virtually the same as for Ludox particles grafted with $\mathrm{C}_{18}$ chains in a melt of octadecyl alcohol; ${ }^{26}$ the $\mathrm{H} / \mathrm{C}$ ratios are even identical. This demonstrates that the grafting in NPOE is a good alternative and that very little NPOE is present on the final particles (as was also concluded from NMR).

Toestimatethechain number density con SCL ${ }_{18} \mathbf{N P O E}$, we usea mass density of $1.6 \mathrm{~g} / \mathrm{mL}$ for grafted $L$ udox ${ }^{26}$ and an averageparticleradius $\mathrm{R}=17 \pm 3 \mathrm{~nm}$. After evaluating the surface area per gram, assuming smooth spheres, it turns out that $\mathrm{c} \approx 3.8 \pm 0.7 \mathrm{~nm}^{-2}$. As most bare silicas have about five silanols per square nanometer ${ }^{34}$ we can conclude that the majority of these silanols (or ethoxy groups) havereacted with octadecyl al cohol to form a fairly dense alkyl layer.

Calix derivate 5 has a lower $\mathrm{H} / \mathrm{C}$ ratio $(\mathrm{H} / \mathrm{C}=1.4)$ than octadecyl alcohol. Indeed we see that SLCALIXNPOE has the lowest $\mathrm{H} / \mathrm{C}$ ratio of all the grafted Ludox systems (see Table 3A). From the carbon content we now find a coverage of $c=1 \pm 0.18$ (calix) molecules per square nanometer. Remarkably, this area of $1 \mathrm{~nm}^{2}$ per molecule is also the value found from Langmuir-Blodgett films. ${ }^{26}$

The cografting produces particles of SLCALIXC $\mathbf{~}_{\mathbf{1 8}}$ NPOE which have, according to NMR, indeed both moieties on thesurface. The carbon content is about half thevaluefor the "singlegrafted"systems for reasons which are not clear.

The elemental analysis results for the Ludox coated in TEP indicatethat this solvent interferes with thegrafting procedure and leads to lower surface coverages. The SLTEP particles, kept in refluxing TEP for several days, still contain TEP, despite the extensive washing procedures with ethanol (The presence of TEP on the particles was also detected by ${ }^{31}$ P MAS NMR). There is 0.8 wt \% phosphorus present, and a molar ratio of $C / P=6.22$, which is close to the value of $C / P=6$ for pure TEP. The phosphorus coverage is about $\mathrm{C} \cong 1.4( \pm 0.17) \mathrm{nm}^{-2}$. So TEP is blocking "anchor sites" for the grafting agents. Theaffinity of TEP for silica could beexplained by a partial transesterification reaction of TEP and the Ludox surface at high temperatures. This would also account for the presence of phosphorus, even after extensivewashing with ethanol, as well as the higher instability against basic hydrolysis.

The adherence of TEP to silica also explains the good colloidal stability of (bare) L udox particles in TEP (section 3.6), because it prevents colloids from touching each other and sticking together as a result of van der Waals attractions. It now also becomes clear why bare silica

(34) Iler, R. K. The Chemistry of Silica; Wiley: New York, 1979. tends to aggregate in NPOE, as discussed in section 3.6, because this solvent cannot react with the silica surface.

The SLC $\mathbf{~}_{\mathbf{1 8}}$ TEP and SLCALIXTEP colloids have, because of the partial TEP modification, lower surface grafting densities than their NPOE counterparts. These densities (see Table 3A) have been calculated after subtracting the carbon content from SLTEP, to correct for the presence of carbon from TEP. But even if all carbon is assigned to $\mathrm{C}_{18}$ or calix, the grafting densities are still significantly lower than those for the particles coated in NPOE.

Grafted Stöber Spheres. The ungrafted SA11 spheres contain a significant amount of carbon (see Table 3B) because of ethoxy groups which are incorporated in the particles during the Stöber synthesis. 5,6

The SA11TEP particles, kept in refluxing TEP for several days, still contain TEP, just as do the Ludox partides, despiteextensivewashing procedures. Themass densities of Stöber spheres are typically $1.8( \pm 0.1) \mathrm{g} / \mathrm{mL}$. Assuming smooth spheres with a radius $\mathrm{R}=90 \mathrm{~nm}$, we find from the phosphorous content a TE P coverage of about $c=1 \mathrm{~nm}^{-2}$ on the silica surface. (The grafting densities for particles grafted in TEP, given in Table 3B, are calculated after subtracting the carbon content of the SA11TEP particles.)

3.8. Complexation Reactions. The resolution and sensitivity of the ${ }^{1} \mathrm{H}$ MAS NMR experiments alsofacilitate the monitoring of interactions of the organic coating with species in the solvent. Upon complexation of SLCALIXNPOE dispersed in $\mathrm{CDCl}_{3}$ with a saturated $\mathrm{CS}^{+}$solution, significant changes in the ${ }^{1} \mathrm{H}$ MAS spectrum can be observed (Figure 6B vs Figure 6A). The observed downfield resonance shifts of the aromatic and $\mathrm{OCH}_{2}$ protons indicate that the $\mathrm{Cs}^{+}$cation is complexed in the crown moiety and al sostrongly interacts with thearomaticrings. The complexation-induced chemical shifts can be established unequivocally by means of a ${ }^{1} \mathrm{H}$ MAS TOCSY experiment (Figure 6D). The structural detail revealed by ${ }^{1} \mathrm{H}$ MAS N MR for colloidal receptors in the dispersed stateis to our knowledgeunprecedented and has potential for further studies on the dynamics of colloidal complexation.

3.9. Electrophoresis. Thequal itativeelectrophoresis experiments for particles in NPOE gave the following results. SA11NPOE colloids in NPOE accumulated at the positive electrode and, hence, carry negative surface charge. The same observation was made for the grafted particles SA11CALIXNPOE and SA11C $_{\mathbf{1 8}^{-}}$ CALIXNPOE: the surface of the negative electrode remained clean, and a clearly visible deposit was formed after about $12-24 \mathrm{~h}$ on the positive electrode. A negative surface charge on grafted silica in (weakly) polar organic solvents is quitecommon and is possibly dueto dissociation of unreacted surface silanol groups. ${ }^{3}$ The $\mathbf{C A L I X \mathbf { X } _ { \mathbf { 1 8 } }}$ NPOE particles, after the compl exation experiment from section 2.3transfer red to pureNPOE, accumulated at the negative electrode. The experiment was repeated with several samples, with thesame outcome. This shows that thepartidesare positively charged. This unusual behavior for silica particles is consistent with the presence of cesium cations on the surface which apparently outweigh the number of negative surface species. The fact that the complexed particles move at all in an electrical field suggests that the (chloride) counterions are relatively free to join the diffuse electrical double layer around the particles, instead of forming ion pairs with $\mathrm{Cs}^{+}$on the silica surface.

\section{Conclusions}

We have studied synthesis procedures and properties of stable organic dispersions of silica col loids grafted with 
receptor molecules and/or alkyl chains. The receptor is a calix[4]arene-crown-6 with two pendant alkyl chains with terminal $\mathrm{OH}$ groups for reaction with surfacesilanol groups from silica particles. Preliminary complexation experiments indicate that the grafted colloids collect cesium cations from their environment, as confirmed by NMR. Electrophoresi s is consistent with a positive silica surface charge due to the complexed cations.

The receptor with alkyl chains and the grafting procedure (both silica colloids and grafting agentsin refluxing organic solvent) were designed to mi mic the conventional method for esterification of silica with a long-chain al cohol. Our results show that this approach works. A variety of techniques and observations (NMR, light scattering, colloidal stability, elemental analysis) confirm the presence of the expected organic groups (receptors, alkyl chains), firmly attached to the surface of the silica particles. Pertinent results are calix[4]arene-modified silica spheres in chloroform and $\mathrm{C}_{18}$-coated spheres in cyclohexane which disperse easily, even after previous drying.

Another significant finding is that the solvent in which grafting takes place is a key to obtain stable dispersions of particles with a high grafting density. A suitable combination of solvent and type of silica is a first requirement for the synthesis of stable receptor colloids. There seem to betwosomewhat conflicting requirements. A solvent such as triethyl phosphate (TEP) partly covers a silica particle, promoting colloidal stability. The drawback is a lower grafting density of receptor molecules. A solvent such as NPOE, on the other hand, does not react with silica. This promotes a high grafting density because there are no blocked "anchor sites" for the grafting agent. The drawback here is a tendency for small Ludox silica particles to flocculate.

The Stöber silica spheres do not have this tendency to aggregate in NPOE. This suggests that Stöber silica particles in NPOE is an appropriate solvent-silica combination for further study of receptor colloids.

Acknowledgment. Mrs. H. Visser (Twente University) is acknowledged for her hel p in theNMR experiments. Dr. G. M. H. van de Velde (Laboratory of Inorganic Materials Science, Twente University) is thanked for performing differential scanning calorimetry. Mr. B. Kuipers (Van't Hoff Laboratory, Utrecht University) performed light-scattering measurements. The electrophoresis experiment was based on a suggestion of Prof. J. Th. G. Overbeek. Dr. J. M. Kroon and Prof. E. J . R. Sudhölter from the Department of Organic Chemistry, Agricultural University of Wageningen, are thanked for performing and interpreting the LB film measurements, and Marina Uit deBulten and HannekedeVries for typing the manuscript.

LA9600659 